\title{
Establishing a normal range for induced sputum cell counts in Western Canada
}

\author{
Warren J Davidson MD, Stephanie The BSc, Richard Leigh MD PhD
}

WJ Davidson, S The, R Leigh. Establishing a normal range for induced sputum cell counts in Western Canada. Can Respir J $2013 ; 20(6): 424-428$.

BACKGROUND: Induced sputum cell counts are a noninvasive, reliable method for evaluating the presence, type and degree of airway inflammation. Whether current reference values for induced sputum cell counts are applicable in other induced-sputum laboratories, particularly those in Western Canada or at elevated altitude, is not clear.

OBJECTIVES: To describe the normal range of induced sputum cell counts in healthy adults in Western Canada.

METHODS: A total of 105 healthy nonsmoking adults with normal bronchial responsiveness and no history of lung disease proceeded with sputum induction. Sputum samples were fixed in formalin.

RESULTS: Sixty-nine subjects were included in the final analyses. The mean \pm SD and median (interquartile range) of the cell counts, respectively, were: total cell count $2.453 \pm 2.108,2.000$ (2.512); neutrophils $1.212 \pm 1.491,0.721$ (1.016); eosinophils $0.034 \pm 0.069,0.005$ (0.043); macrophages $1.050 \pm 1.213,0.696$ (1.005); lymphocytes $0.057 \pm 0.161$, 0.001 (0.049); and bronchial epithelial cells $0.041 \pm 0.126,0.000(0.027)$. The respective differential cell percentages were: neutrophils $50.3 \pm 23.5$,

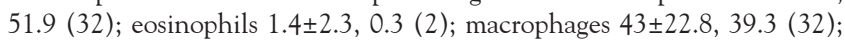
lymphocytes 2.6 $\pm 5.2,0.4$ (2.5); and bronchial epithelial cells $2.2 \pm 4.8$, 0.0 (2.9). Bland-Altman analysis and intraclass correlation coefficients revealed excellent interobserver agreement for measurement of sputum cell types.

DISCUSSION: The range of induced sputum cell counts performed in a laboratory in Western Canada in healthy nonsmoking adult subjects was described; cellular distributions were similar to previous studies. This was also the first description of normal values for formalin-fixed induced sputum samples.

CONCLUSIONS: These results confirm that current reference values for induced sputum are generalizable across different laboratories, including those in Western Canada and those at elevated altitude, and are also generalizable to formalin-fixed samples, allowing use in the broader Canadian asthma population.

Key Words: Airway inflammation; Induced sputum; Reference values

\section{L'établissement d'une plage normale de numérations cellulaires dans les expectorations induites dans l'Ouest canadien}

HISTORIQUE : Les numérations cellulaires dans les expectorations induites sont une méthode fiable et non invasive pour évaluer la présence, le type et le degré d'inflammation des voies aériennes. On ne sait pas si les valeurs de référence à jour de ces numérations sont applicables à d'autres laboratoires d'expectoration induite, notamment dans l'Ouest canadien ou à haute altitude.

OBJECTIFS : Décrire la plage normale de numérations cellulaires dans les expectorations induites chez des adultes en santé de l'Ouest canadien.

MÉTHODOLOGIE : Au total, 105 non-fumeurs adultes et en santé dont la réactivité bronchique était normale et qui n'avaient pas d'antécédents de maladie pulmonaire ont été soumis à une induction d'expectorations. Les échantillons d'expectorations étaient fixés au formol.

RÉSULTATS : Soixante-neuf sujets ont fait partie de l'analyse finale. Les numérations cellulaires moyenne \pm ÉT et médiane (plage interquartile), respectivement, s'établissaient comme suit : numération cellulaire totale $2,453 \pm 2,108,2,000$ (2,512), neutrophiles $1,212 \pm 1,491,0,721$ (1,016), éosinophiles $0,034 \pm 0,069,0,005(0,043)$, macrophages $1,050 \pm 1,213,0,696(1,005)$, lymphocytes $0,057 \pm 0,161,0,001(0,049)$ et cellules épithéliales bronchiques $0,041 \pm 0,126,0,000(0,027)$. Les pourcentages cellulaires différentiels respectifs s'établissaient comme suit : neutrophiles 50,3 $\pm 23,5,51,9$ (32); éosinophiles $1,4 \pm 2,3,0,3$ (2); macrophages $43 \pm 22,8,39,3$ (32); lymphocytes $2,6 \pm 5,2,0,4(2,5)$ et cellules épithéliales bronchiques 2,2 $\pm 4,8,0,0(2,9)$. Lanalyse de Bland-Altman et les coefficients de corrélation intraclasse ont révélé une excellente concordance interobservateur quant à la mesure des types de cellules d'expectoration.

EXPOSÉ : Les chercheurs ont décrit la plage de numérations cellulaires dans les expectorations induites effectuées dans un laboratoire de l'Ouest canadien chez des non-fumeurs adultes en santé. Les distributions cellulaires étaient similaires à celles d'études antérieures. C'est également la première description de valeurs normales d'échantillons d'expectorations induites fixées au formol.

CONCLUSIONS : Ces résultats confirment que les valeurs de référence à jour des expectorations induites peuvent être généralisées dans divers laboratoires, y compris ceux de l'Ouest canadien et à haute altitude, de même que dans des échantillons fixés au formol, ce qui permet de les utiliser dans l'ensemble de la population atteinte d'asthme au Canada.

Induced sputum cell counts are a noninvasive, reliable method for evaluating the presence, type and degree of inflammation in the airways of the lungs (1-3). Sputum cell counts have been used to assist with the management of underlying airway inflammation, including assessment of asthma control and titration of inhaled corticosteroid therapy in patients with asthma (4). Adjusting asthma management based on sputum eosinophil counts has been found to be effective in reducing asthma exacerbations (4-7) and is now considered to be standard of care for the management of difficult-to-control asthma in the Canadian asthma guidelines (8).

Previous studies assessing the cellular profile of induced sputum in healthy subjects, compared with asthma and chronic obstructive pulmonary disease patients $(9,10)$, were limited by very small sample sizes and differences in sample collection. Current reference values for absolute and percentage induced sputum cell counts in healthy adults were derived from two major studies performed $>12$ years ago $(11,12)$. However, only the study by Belda et al (11) assessed absolute sputum cell counts. Furthermore, compared with the results from Belda et al, Spanevello et al (12) reported a lower percentage of sputum neutrophils and a higher percentage of sputum macrophages. In addition to these differences, it is unclear whether the results are generalizable to other sputum laboratories, including those in Western Canada or at elevated altitude.

In Calgary (Alberta), induced sputum collection and processing was initiated in 2005 as part of the Department of Medicine Innovation funding program. Our laboratory, located $1074 \mathrm{~m}$ above sea level, has been using the reference range for total sputum cell count and sputum differential cell percentages derived from Belda et al (11). The clinical use of induced sputum testing continues to increase; to date, we have analyzed approximately 3100 clinical samples from within the Calgary region and surrounding referral areas.

Understanding whether the current reference values are applicable in other laboratories that process clinical samples will help standardize our interpretation of induced sputum cell counts in the clinical

Department of Medicine, University of Calgary, Calgary, Alberta

Correspondence: Dr Warren Davidson, 7007-14th Street Southwest, Calgary, Alberta T2V 1P9. Telephone 403-943-8864,

fax 403-943-8666, e-mail wdavidso@ucalgary.ca 
investigation and management of inflammatory airways disorders. The aim of the present study was to describe the normal range of induced sputum cell counts in healthy, nonsmoking adults in Calgary and compare these with current reference values. We hypothesized that the range of induced sputum cell counts would be similar to those reported by Belda et al (11).

\section{METHODS}

\section{Participants}

The present study was approved by the institutional research ethics board and written informed consent was obtained from all subjects. Adult study and control participants were eligible for inclusion in the study provided they were nonsmokers who had no history of any chronic respiratory conditions and had normal spirometry (forced expiratory volume in $1 \mathrm{~s}\left[\mathrm{FEV}_{1}\right]>80 \%$ predicted and $\mathrm{FEV}_{1}$ to forced vital capacity [FVC] ratio $>0.75$ ), with no significant bronchodilator response $\left(\mathrm{FEV}_{1}<200 \mathrm{~mL}\right.$ increase and $\mathrm{FVC}<12 \%$ increase following short-acting bronchodilator administration). Potential study participants were excluded from the study if they had any of the following: a positive methacholine challenge test (defined as a provocative concentration of methacholine required to cause a $20 \%$ reduction in baseline $\mathrm{FEV}_{1}\left[\mathrm{PC}_{20}\right]<16 \mathrm{mg} / \mathrm{mL}$ ); a smoking history $\geq 5$ pack years or had smoked within the past 12 months; a history of atopy; a history of rhinitis symptoms; an upper respiratory tract infection four weeks before study participation; or a history of any inflammatory condition considered by the investigators to be clinically relevant, including any underlying autoimmune disorder, infectious disease, immunodeficiency, malignancy or clinically relevant cardiovascular, neurological, endocrine or hematological disorder. Women who were pregnant or who were planning on become pregnant during the study period, and women who were breastfeeding were also excluded. Finally, only individuals who provided written informed consent were included in the study.

\section{Study design}

The primary objective of the present analysis was to describe the normal range of induced sputum cell counts in healthy adults attending a clinical induced sputum program in Western Canada.

Study participants attended the laboratory on three separate occasions. During the first visit, the subject's medical history was reviewed to determine whether they met the inclusion/exclusion criteria, and pre- and postbronchodilator spirometry was completed. At visit 2, subjects underwent the methacholine challenge test. Induced sputum collection was performed at visit 3 .

\section{Procedures}

Pulmonary function testing: Spirometry, pre- and postbronchodilator administration, and methacholine challenge testing were performed according to American Thoracic Society guidelines $(13,14)$.

Sputum induction and processing: Induced sputum collection was performed using accepted techniques as per standardized guidelines (15). Briefly, sputum was induced using escalating concentrations of hypertonic saline $(4 \%, 4 \%, 5 \%)$. Subjects inhaled the hypertonic saline for $7 \mathrm{~min}$ for each concentration. If the baseline $\mathrm{FEV}_{1}$ fell by $>20 \%$ or if the subject experienced respiratory distress, the procedure was discontinued and treatment with inhaled bronchodilator was given. Spirometry was repeated to ensure that $\mathrm{FEV}_{1}$ improved to within $10 \%$ of baseline. After induction, $10 \mathrm{~mL}$ of $10 \%$ buffered formalin (Starplex Scientific Inc, Canada) was added to the expectorated sample (16). Samples were then processed within two to five days after collection. The expectorated preserved sputum was poured into a petri dish and examined. Mucus plugs were selected and contaminating saliva was removed. The sample was suspended in phosphate-buffered saline and rocked for $10 \mathrm{~min}$ before being centrifuged ( $500 \times \mathrm{g}$ for $10 \mathrm{~min}$ ). After centrifugation, the supernatant was removed and the sample was briefly vortexed. These steps were repeated three times. The sample was weighed, and a solution of $2.5 \%$ trypsin (three times volume to

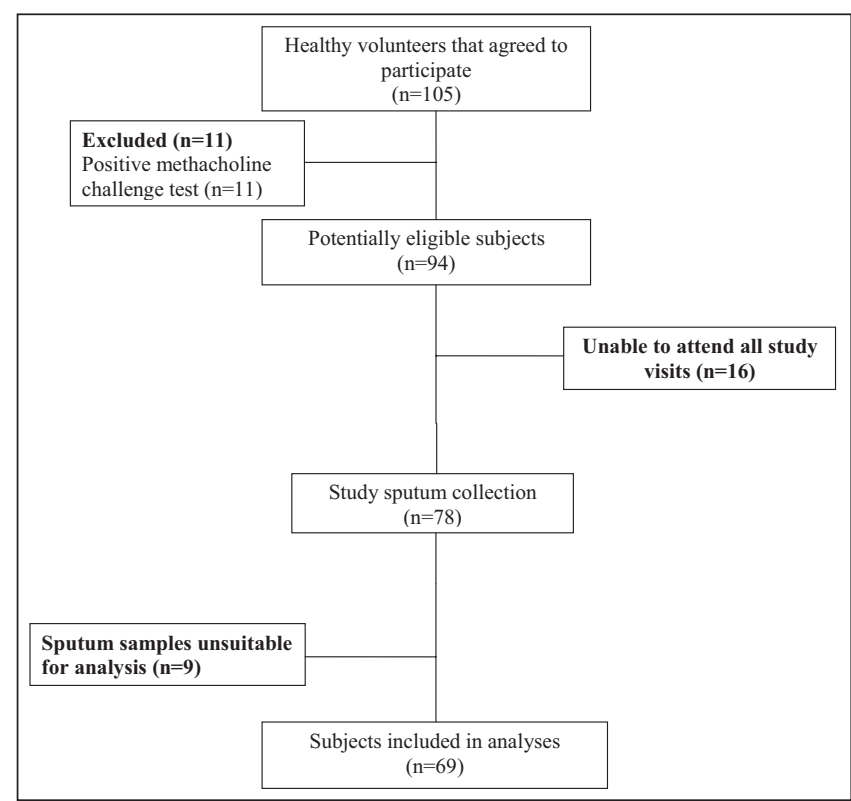

Figure 1) Subject flow

sputum weight) was added to the sample and the solution was then incubated at $37^{\circ} \mathrm{C}$ overnight ( $16 \mathrm{~h}$ to $17 \mathrm{~h}$ ). Total cell counts were obtained manually using a Bright-line Neubuer hemacytometer (Hausser Scientific, USA). The cells were diluted to $1 \times 10^{6} / \mathrm{mL}$ in phosphate buffered saline and cytospin slides were prepared before staining with Congo Red, after which differential sputum cell counts were performed on 400 nonsquamous cells. Cell viability could not be determined using this formalin preservation method, which was established in a previous publication by Kelly et al (17) validating this method. Samples were considered to be adequate for analysis if squamous cell contamination was $<20 \%$. Measurements were compared with standardized values (11). Cell counts were performed by an experienced cytotechnologist blinded to subject characteristics and study protocol. To assess interobserver agreement in the differential sputum cell count, the slides from 20 subjects were re-counted by a second experienced cytotechnologist, who was also blinded to subject characteristics and the study protocol.

\section{Statistical analyses}

Sputum cell counts were expressed as arithmetic mean \pm SD when normally distributed, or as median (interquartile range [IQR]) when non-normally distributed. The normal range was expressed by mean \pm 2 SD, as well as the median and 10th and 90th percentiles. The difference in the cell counts between men and women was assessed using independent $t$ tests for normally distributed data and Wilcoxon ranksum test for nonparametric data. To account for multiple analyses, $\mathrm{P}<0.01$ was considered to be statistically significant. The effect of spirometric measurements (absolute and per cent predicted) on sputum cell counts was assessed using linear regression. Significance was accepted at $95 \%$. To assess interobserver agreement in the differential sputum cell count, Bland-Altman plots were performed and intraclass correlation coefficients (ICC) were calculated.

\section{Study subjects}

\section{RESULTS}

Subject enrollment began in January 2010 and ended in March 2012. Subject flow is summarized in Figure 1. Of the 105 subjects who volunteered to participate, 11 were excluded due to a positive methacholine challenge test, 16 were withdrawn due to difficulties attending all required study visits and nine were excluded because at least one of their sputum samples was unsatisfactory for interpretation. Sixty-nine 


\section{TABLE 1}

Baseline characteristics of subjects

\begin{tabular}{|c|c|}
\hline Characteristic & \\
\hline Age, years & $35.7 \pm 9.8$ \\
\hline Male:female, n:n & $26: 43$ \\
\hline \multicolumn{2}{|l|}{ Ethnicity, n (\%) } \\
\hline Caucasian & $54(78)$ \\
\hline Asian & $10(14)$ \\
\hline Other & $5(8)$ \\
\hline Body mass index, $\mathrm{kg} / \mathrm{m}^{2}$ & $24.55 \pm 3.85$ \\
\hline Smoking, pack-years & $0.3 \pm 1$ \\
\hline $\mathrm{FEV}_{1}, \mathrm{~L}$ & $3.70 \pm 0.79$ \\
\hline $\mathrm{FEV}_{1}, \%$ predicted & $106 \pm 12.2$ \\
\hline FVC, L & $4.65 \pm 1.04$ \\
\hline FVC, $\%$ predicted & $108 \pm 18.7$ \\
\hline $\mathrm{FEV}_{1} / \mathrm{FVC}$ & $0.80 \pm 0.06$ \\
\hline
\end{tabular}

Data presented as mean $\pm S D$ unless otherwise indicated. FEV ${ }_{1}$ Forced expiratory volume in $1 \mathrm{~s}$; FVC Forced vital capacity

subjects were included in the final analyses. Subject characteristics are summarized in Table 1 . The majority of the subjects were Caucasian $(n=54)$ and female $(n=43)$. The study population had normal spirometry. None of the subjects were taking regular medications at the time of enrollment.

Induced sputum cell counts

The median sputum weight was $0.60 \mathrm{~g}$ (IQR $0.26 \mathrm{~g}$ to $1.56 \mathrm{~g}$ ), similar to previously reported values (18). Table 2 summarizes the induced sputum total and differential cell counts $\left(\times 10^{6}\right.$ cells/g). Table 3 summarizes the range of induced sputum differential cell percentages. The majority of cells were neutrophils and macrophages.

Sputum cell counts (cells/g and percentage) were compared according to subjects' sex and spirometric measurements (absolute values and per cent predicted) (Table 4). Absolute FEV 1 and FVC were higher in men but the per cent predicted measurements were not different. No significant differences in sputum cell types were found between male and female subjects. No sputum cell type showed a significant relationship with spirometric measurements.

Inter- and intraobserver agreement

Sputum samples from 20 subjects were randomly selected for differential sputum cell count interpretation by a second cytotechnician blinded to subject characteristics and study protocol. Bland-Altman analysis revealed very good interobserver agreement (Figure 2, Table 5). The ICC revealed excellent agreement for the cell types (Table 5). Intraobserver agreement was performed on an additional 20 randomly selected subject samples. Bland-Altman analysis and ICC showed excellent agreement (Table 6).

\section{DISCUSSION}

The present study described the normal range of induced sputum cell counts performed in a laboratory in Western Canada involving healthy, nonsmoking adult subjects and found cellular distributions to be similar to previous studies $(11,12)$. We extended the observations from those studies by performing interobserver agreement for interpretation of the differential sputum cell count and confirmed that the results were reliable. Furthermore, the present report is the first to describe normal values for formalin-fixed induced sputum samples.

The median total sputum cell count in our study fell between the median values from the studies by Belda et al (11) and Spanevello et al (12). Although the sputum absolute and percentage cell counts most closely resembled those of Belda et al (11), the total and absolute neutrophil cell counts were lower in our study, in addition to variability in these cell counts. We found a slightly lower percentage neutrophil count. Eosinophil cell counts (absolute and percentage) were only slightly higher in our study, as was the variability in the range of these values. Macrophage cell counts were lower, while lymphocyte and bronchial epithelial cell counts were only slightly higher. Compared with the findings reported by Spanevello et al (12), our results showed a higher percentage of sputum neutrophils and a lower percentage of macrophages. The differences may be a result of the formalin fixation method used in our study. Formalin is believed to rapidly inactivate cellular enzymes and stabilize the cell membrane when added to induced sputum samples (17). It is possible that use of the preservation technique may have improved cell viability and cellular recovery compared with previous studies reporting normal cell count values. Similar to Belda et al (11), we found no significant relationship with sputum cell counts and spirometric measurements. There was also no difference in absolute or percentage sputum cell counts between male and female subjects. Our results differ from those of Belda et al (11), who found that absolute and percentage eosinophil counts were higher in females (absolute counts: mean difference $0.003 \times 10^{6}$ cells $/ g$ [95\% CI $0.000 \%$ to $0.015 \%$ ]; $\mathrm{P}=0.049$; percentage counts: $0.274 \%$ [95\% CI $0.001 \%$ to $0.651 \%$ ]; $\mathrm{P}=0.043$ ). Our study had fewer subjects and may have been underpowered to detect this subgroup difference.

TABLE 2

Normal range of induced sputum total and differential cell counts $\left(\times 10^{6}\right.$ cells $\left./ \mathrm{g}\right)$

\begin{tabular}{lcccccc}
\hline & & & & \multicolumn{2}{c}{ Percentile } \\
\cline { 5 - 7 } & Mean \pm SD & Mean -2 SD & Mean +2 SD & (interquartile range) & 10th & 90th \\
\hline Total cell count & $2.453 \pm 2.108$ & -1.763 & 6.669 & $2.000(2.512)$ & 0.328 \\
Neutrophils & $1.212 \pm 1.491$ & -1.77 & 4.194 & $0.721(1.016)$ & 0.159 & 2.038 \\
Eosinophils & $0.034 \pm 0.069$ & -0.104 & 0.172 & $0.005(0.043)$ & 0.000 & 0.096 \\
Macrophages & $1.050 \pm 1.213$ & -1.376 & 3.476 & $0.696(1.005)$ & 0.108 & 1.914 \\
Lymphocytes & $0.057 \pm 0.161$ & -0.265 & 0.379 & $0.001(0.049)$ & 0.000 & 0.138 \\
Bronchial epithelial cells & $0.041 \pm 0.126$ & -0.211 & 0.293 & $0.000(0.027)$ & 0.000 & 0.089 \\
\hline
\end{tabular}

TABLE 3

Normal range of induced sputum differential cell percentages

\begin{tabular}{|c|c|c|c|c|c|c|}
\hline & \multirow[b]{2}{*}{ Mean \pm SD } & \multirow[b]{2}{*}{ Mean -2 SD } & \multirow[b]{2}{*}{ Mean +2 SD } & \multirow{2}{*}{$\begin{array}{c}\text { Median } \\
\text { (interquartile range) }\end{array}$} & \multicolumn{2}{|c|}{ Percentile } \\
\hline & & & & & 10th & 90th \\
\hline Neutrophils & $50.3 \pm 23.5$ & 3.3 & 97.3 & $51.9(32)$ & 15.0 & 82.2 \\
\hline Eosinophils & $1.4 \pm 2.3$ & -3.2 & 6.0 & $0.3(2)$ & 0.0 & 4.5 \\
\hline Macrophages & $43.0 \pm 22.8$ & -2.6 & 88.6 & $39.3(32)$ & 14.0 & 73.8 \\
\hline Lymphocytes & $2.6 \pm 5.2$ & -7.8 & 13.0 & $0.4(2.5)$ & 0.0 & 7.0 \\
\hline Bronchial epithelial cells & $2.2 \pm 4.8$ & -7.4 & 11.8 & $0.0(2.9)$ & 0.0 & 7.3 \\
\hline
\end{tabular}


TABLE 4

Spirometry and induced sputum results according to sex

\begin{tabular}{|c|c|c|c|}
\hline & Male & Female & $\mathbf{P}$ \\
\hline Patients, $n$ & 26 & 43 & \\
\hline Age, years & $34.7 \pm 8.2$ & $36.3 \pm 10.8$ & 0.50 \\
\hline Pack-year history & $0.12 \pm 0.33$ & $0.42 \pm 1.26$ & 0.23 \\
\hline $\mathrm{FEV}_{1}, \mathrm{~L}$ & $4.29 \pm 0.7$ & $3.34 \pm 0.61$ & $<0.0001$ \\
\hline $\mathrm{FEV}_{1}, \%$ predicted & $103 \pm 12.2$ & $108.2 \pm 11.9$ & 0.085 \\
\hline FVC, L & $5.41 \pm 0.92$ & $4.18 \pm 0.82$ & $<0.0001$ \\
\hline FVC, \% predicted & $105.2 \pm 11.8$ & $109.7 \pm 21.7$ & 0.33 \\
\hline $\mathrm{FEV}_{1} / \mathrm{FVC}$ & $0.80 \pm 0.06$ & $0.80 \pm 0.06$ & 0.61 \\
\hline Total cell count, $\times 10^{6} \mathrm{cells} / \mathrm{g}$ & $2.562 \pm 2.367$ & $2.388 \pm 1.961$ & 0.70 \\
\hline Neutrophils, $\times 10^{6} \mathrm{cells} / \mathrm{g}$ & $1.262 \pm 1.610$ & $1.181 \pm 1.434$ & 0.66 \\
\hline Neutrophils, \% & $46.9 \pm 23.6$ & $52.3 \pm 23.6$ & 0.36 \\
\hline Eosinophils ${ }^{*}, \times 10^{6}$ cells $/ g$ & $0.005(0.041)$ & $0.004(0.056)$ & 0.87 \\
\hline Eosinophils* ${ }^{*} \%$ & $0.3(1.5)$ & $0.3(3.1)$ & 0.73 \\
\hline Macrophages ${ }^{*}, \times 10^{6}$ cells $/ \mathrm{g}$ & $0.973(1.214)$ & $0.655(0.846)$ & 0.43 \\
\hline Macrophages ${ }^{*}, \%$ & $45.7(24)$ & $41.3(22.2)$ & 0.47 \\
\hline Lymphocytes ${ }^{*} \times 10^{6}$ cells/g & $0.0(0)$ & $0.004(0.049)$ & 0.72 \\
\hline Lymphocytes*, \% & $0.0(0)$ & $1.0(2.8)$ & 0.93 \\
\hline $\begin{array}{l}\text { Bronchial epithelial cells }{ }^{*} \text {, } \\
\times 10^{6} \text { cells } / \mathrm{g}\end{array}$ & $0.014(0.027)$ & $0.0(0.013)$ & 0.08 \\
\hline Bronchial epithelial cells*, \% & $1.0(3.9)$ & $0.0(2.1)$ & 0.08 \\
\hline
\end{tabular}

Data presented as mean $\pm S D$. *Non-normally distributed variables reported as median (interquartile range). $P$ values derived from the independent $\mathrm{t}$ test for normally distributed data and the Wilcoxon rank-sum test for nonparametric data. FEV ${ }_{1}$ Forced expiratory volume in $1 \mathrm{~s}$; FVC Forced vital capacity

In addition to providing a normal dataset for Western Canada and for induced sputum laboratories located at elevated altitudes, the present report is the first to describe normal values for formalin-fixed induced sputum samples. The use of formalin as a preservation method for induced sputum processing has previously been validated (17). Specifically, Kelly (19) compared two methods of sputum processing: a (para)formaldehyde-dithiothreitol (DTT) mixture dispersed with trypsin (preservation method); and immediate processing with DTT (routine method). Good agreement between the techniques was found, along with good within-method repeatability for the preservation method, thereby confirming that this method is valid and reliable. Furthermore, no increase in degenerative changes and no interference of cell counts by debris were found (19). This technique has subsequently been successfully used to process sputum samples in a remote collection site (20). Additionally, this method of preservation has been shown to have no adverse effect on sample quality and sputum cell counts (16). Use of this preservation technique allows sites that are unable to process sputum to store the sample and send it to a central processing laboratory. This would allow expanded use of induced sputum cell counts, including in rural communities, and make

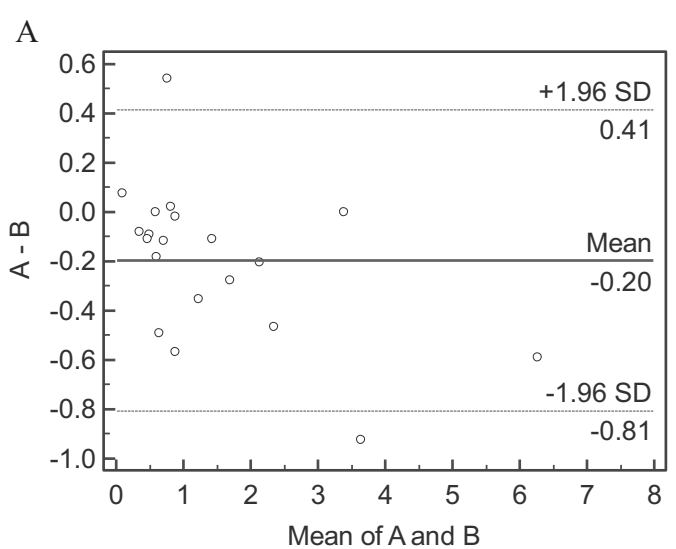

B

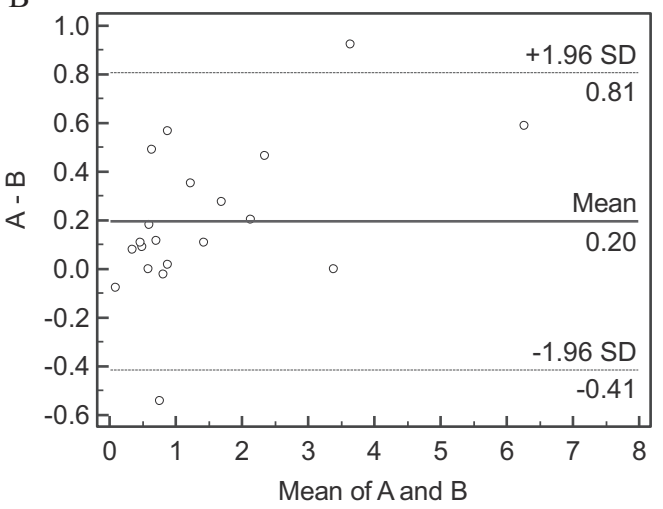

C

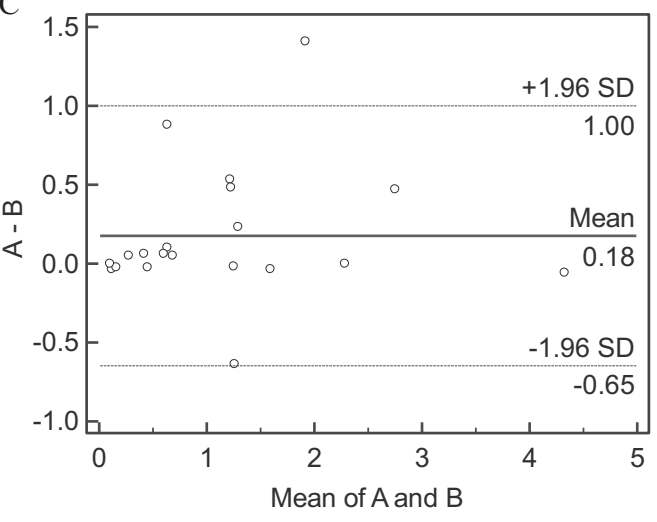

Figure 2) Bland-Altman plots of the interobserver agreement for differential sputum cell counts. Sputum neutrophil, eosinophil, and macrophage cell counts are represented in plots $\mathrm{A}, \mathrm{B}$ and $\mathrm{C}$, respectively. The dashed lines represent the interobserver bias ( $\pm 1.96 \mathrm{SD})$. A First cytotechnologist cell count; B Second cytotechnologist cell count

\section{TABLE 5}

Bland-Altman analysis of interobserver bias in sputum cell counts

\begin{tabular}{|c|c|c|c|}
\hline & Neutrophils, $\times 10^{6}$ cells $/ g$ & Eosinophils, $\times 10^{6} \mathrm{cells} / \mathrm{g}$ & Macrophages, $\times 10^{6}$ cells $/ g$ \\
\hline Interobserver bias, \pm 1.96 STD & $-0.20 \pm 0.61$ & $0.20 \pm 0.61$ & $0.18 \pm 0.82$ \\
\hline Intraclass correlation coefficient $(95 \% \mathrm{Cl})$ & 0.989 (0.973 to 0.996$)$ & 0.963 (0.906 to 0.985$)$ & 0.959 (0.897 to 0.984$)$ \\
\hline
\end{tabular}

STD Standard deviation of the difference

TABLE 6

Bland-Altman analysis of intraobserver bias in sputum cell counts

\begin{tabular}{|c|c|c|c|}
\hline & Neutrophils, $\times 10^{6}$ cells $/ g$ & Eosinophils, $\times 10^{6}$ cells $/ g$ & Macrophages, $\times 10^{6} \mathrm{cells} / \mathrm{g}$ \\
\hline Intra-observer bias, \pm 1.96 STD & $0.06 \pm 0.18$ & $0.002 \pm 0.029$ & $-0.04 \pm 0.14$ \\
\hline Intraclass correlation coefficient $(95 \% \mathrm{Cl})$ & 0.9988 (0.9957 to 0.9996$)$ & 0.916 (0.802 to 0.966$)$ & 0.9995 (0.9980 to 0.9998$)$ \\
\hline
\end{tabular}


the recent Canadian Thoracic Society asthma guideline recommendation to use sputum cell counts in managing moderate-severe asthma more generalizable to the broader Canadian asthma population.

Viability of the preserved cells could not be determined. The standard method of measuring cell viability using the trypan blue exclusion technique (21) was not possible because addition of formalin resulted in cell death. Formalin-preserved cells have good morphology and cell counts, total and differential, and may be performed in the same way as the DTT method (17).

There were a few limitations to the present study. First, our sample size was smaller than the studies from which the current induced sputum cellular reference values were derived. The smaller sample size likely contributed to the higher variability in some of the cell counts (absolute and percentage) compared with previous literature. Despite this, our results were similar to those studies. Second, although subjects with a history of atopy were excluded, we did not perform allergy skin prick testing on all study subjects. Thus, it is possible that some patients may have had latent atopy with no clinical history. Third, due to the preservation technique, we were not able to assess sputum fluidphase mediators such as sputum cytokines.

\section{REFERENCES}

1. Djukanovic R, Sterk PJ, Fahy JV, Hargreave FE. Standardised methodology of sputum induction and processing. Eur Respir J 2002;20(37 Suppl):1s-2s.

2. Pizzichini E, Pizzichini M, Efthimiadis A, et al. Indices of airway inflammation in induced sputum. Reproducibility and validity of cell and fluid-phase measurements. Am J Respir Crit Care Med 1996;154:308-17.

3. Pizzichini E, Pizzichini MM, Leigh R, Djukanovic R, Sterk PJ. Safety of sputum induction. Eur Respir J 2002;(Suppl 37):9s-18s.

4. Green RH, Brightling CE, McKenna S, et al. Asthma exacerbations and sputum eosinophil counts: A randomized controlled trial. Lancet 2002;360:1715-21.

5. Jayaram L, Pizzichini MM, Cook RJ, et al. Determining asthma treatment by monitoring sputum cell counts: Effect on exacerbations. Eur Resp J 2006;27:483-94.

6. Chlumský J, Striz I, Terl M, Vondracek J. Strategy aimed at reduction of sputum eosinophils decreases exacerbation rate in patients with asthma. J Int Med Res 2006;34:129-39.

7. Greene CD, Kelly MM, Hawkins DH, Evans JA, Davidson W, Leigh R. The introduction of induced sputum cell counts in hospital-based asthma clinics significantly reduces asthma-related emergency room visits. Chest 2007;132;437S.

8. MD Lougheed, C Lemiere, FM Ducharme, et al; Canadian Thoracic Society Asthma Clinical Assembly. Canadian Thoracic Society 2012 guideline update: Diagnosis and management of asthma in preschoolers, children, and adults. Can Respir J 2012;19:127-64.

9. Ronchi MC, Piragino C, Rosi E, Amendola M, Duranti R, Scano G. Role of sputum differential cell count in detecting airway inflammation in patients with chronic bronchial asthma or COPD. Thorax 1996;51:1000-4.

10. Holz O, Jörres RA, Koschyk S, Speckin P, Welker L, Magnussen H. Changes in sputum composition during sputum induction in healthy and asthmatic subjects. Clin Exp Allergy 1998;28:284-92.

\section{CONCLUSION}

The present study described the normal range of induced sputum cell counts in healthy adult subjects and found cellular distributions similar to currently cited reference values. Moreover, the present report is the first to describe normal sputum cell counts in formalin-fixed samples. Our results confirm that current reference values for induced sputum testing are generalizable across different laboratories, including those in Western Canada and those at elevated altitudes, and are also generalizable to formalin-fixed samples.

COMPETING INTERESTS: The authors have no potential conflicts of interest related to this study.

FUNDING: This study was supported by a University of Calgary, Department of Medicine Research Fund Award.

ETHICS APPROVAL: Institutional Research Ethics Board, University of Calgary, Calgary, Alberta.
11. Belda J, Leigh R, Parameswaran K, O'Byrne PM, Sears MR, Hargreave FE. Induced sputum cell counts in healthy adults. Am J Respir Crit Care Med 2000;161:475-8.

12. Spanevello A, Confalonieri M, Sulotto F, et al. Induced sputum cellularity. Reference values and distribution in normal volunteers. Am J Resp Crit Care Med 2000;162(3 Pt 1):1172-4.

13. Standardization of spirometry, 1994 Update. American Thoracic Society. Am J Respir Crit Care Med 1995;152:1107-3.

14. Guidelines for methacholine and exercise challenge testing -1999. Am J Respir Crit Care Med 2000;161:309-29.

15. Efthimiadis A, Spanevello A, Hamid Q, et al. Methods of sputum processing for cell counts, immunocytochemistry and in situ hybridisation. Eur Respir J 2002;(Suppl 37):19s-23s.

16. Hasan SA, Traves SL, Leigh R, Kelly MM. A method to allow preservation and delayed examination of induced, unselected sputum. Am J Respir Crit Care Med 2010;181:A4276.

17. Kelly MM, Hargreave FE, Cox G. A method to preserve sputum for delayed examination. Eur Respir J 2003;22:996-1000.

18. Pizzichini E, Pizzichini MMM, Efthimiadis A, Hargreave FE, Dolovich J. Measurement of inflammatory indices in induced sputum: Effects of selection of sputum to minimize salivary contamination. Eur Respir J 1996;9:1174-80.

19. Kelly MM. Re: Dorman SC, Bussoli MA, Ritz SA. Alcohol fixation of induced sputum samples for applications in rural communities. Can Respir J 2010;17:115-121. Can Respir J 2010;17:236.

20. Swiston JR, Davidson W, Attridge S, Li GT, Brauer M, van Eeden SF. Wood smoke exposure induces a pulmonary and systemic inflammatory response in firefighters. Eur Respir J 2008;32:129-38.

21. Strober W. Trypan blue exclusion test of cell viability. Current Protoc Immunol 2001;Appendix 3:Appendix 3B. 


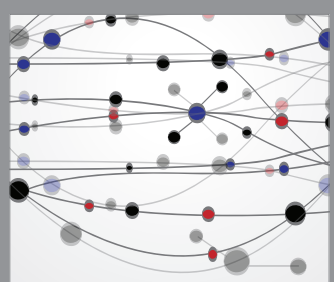

The Scientific World Journal
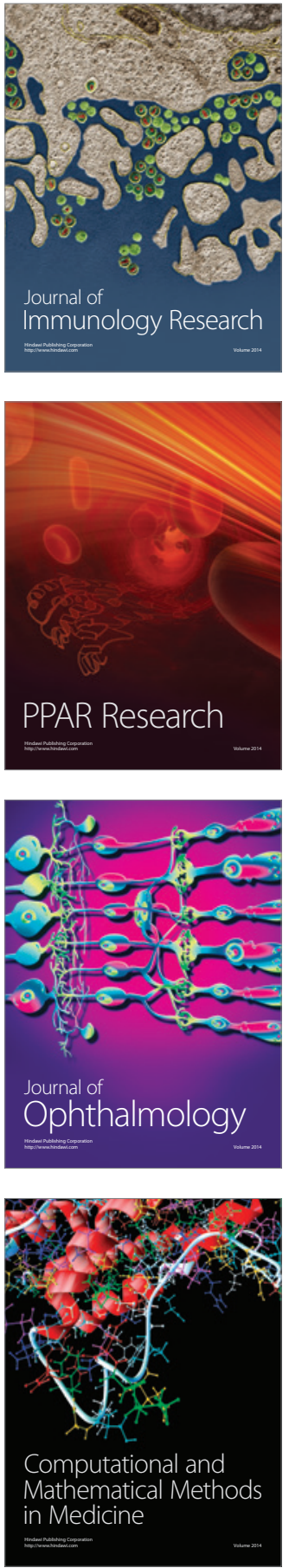

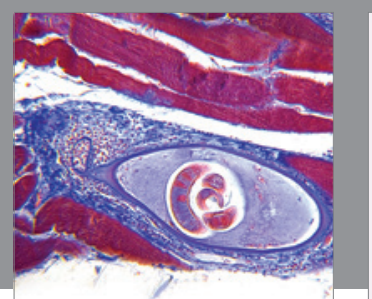

Gastroenterology Research and Practice

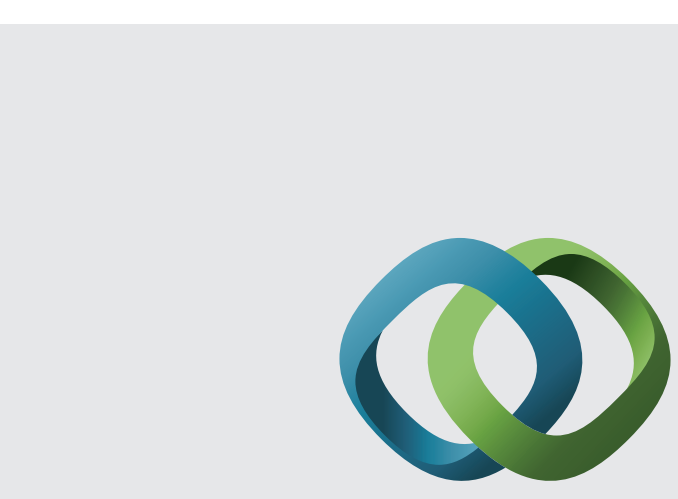

\section{Hindawi}

Submit your manuscripts at

http://www.hindawi.com
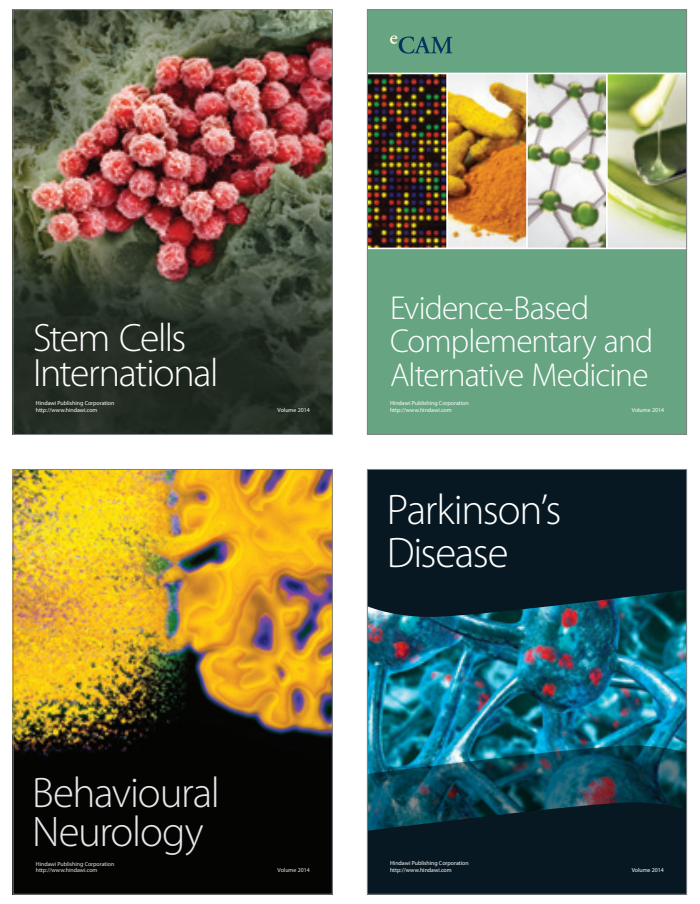
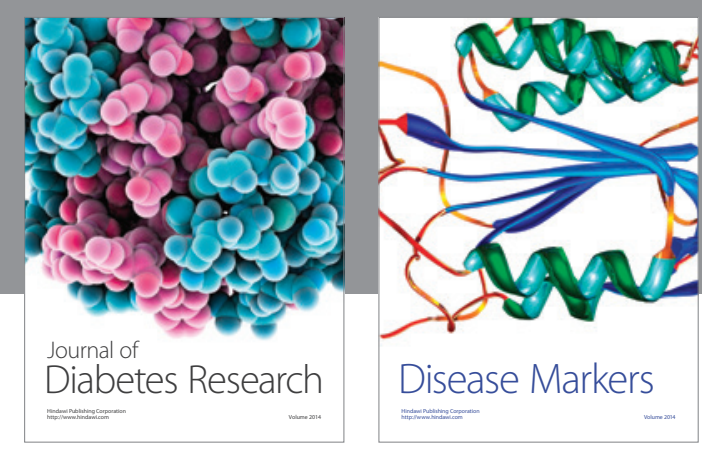

Disease Markers
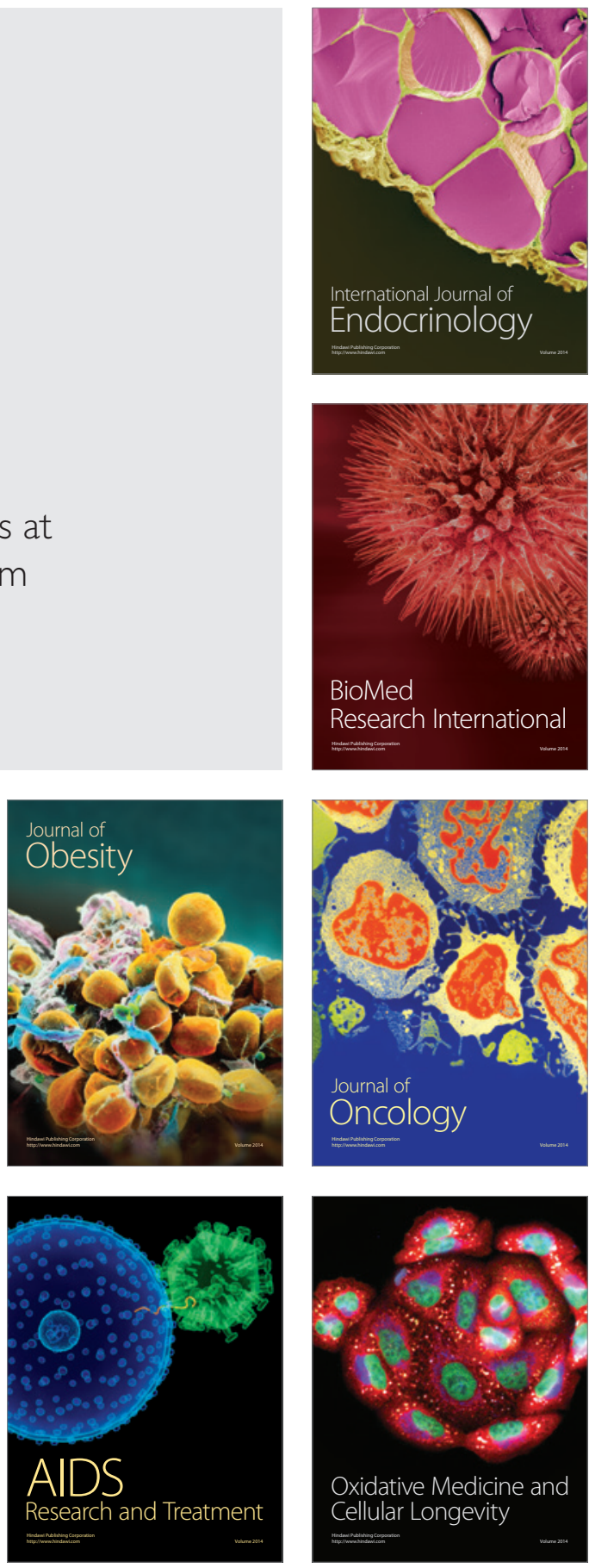